\title{
Spelling Accuracy of Consonants in Arabic among Negev Bedouin Students
}

\author{
Alon Fragman \\ Middle Eastern Studies Department, Ben Gurion University, Be'er Sheva, Israel \\ Email: fragman@bgu.ac.il
}

Received July 23 $3^{\text {rd }}, 2013$; revised August $26^{\text {th }}, 2013$; accepted September $5^{\text {th }}, 2013$

\begin{abstract}
Copyright (c) 2013 Alon Fragman. This is an open access article distributed under the Creative Commons Attribution License, which permits unrestricted use, distribution, and reproduction in any medium, provided the original work is properly cited.
\end{abstract}

\begin{abstract}
This study explored spelling development of the written form of Arabic among native Bedouin Arabic (BA) speakers in second, fourth, and sixth grades $(\mathrm{N}=347)$ from two recognized authorities in south Israel. Specifically, this study focused on guttural $(/ \mathrm{h} /)$, uvular-velar $(/ \mathrm{q} /$ and $/ \dot{\mathrm{g}} /)$, emphatic $(/ \mathbf{d} \mathbf{d} / /$, $/ \mathrm{t} t /$, and $/ \underline{\delta} /)$, and dental $(/ \mathrm{t} /)$ consonants. Three tasks were constructed for this study: real word dictation, pseudo-word dictation, and real word recognition. The results for the real word task, pseudo-word task, and the word recognition task indicated significant improvement in spelling accuracy of the consonants targeted among fourth graders, however there was no additional improvement among the students in the sixth grade. It was also found that with emphatic phonemes accuracy is significantly lower than with all other phonemic groups at all elementary grades. In addition, gender differences were observed with significantly higher scores for girls in all grades targeted for all tasks. Pedagogical implications of these findings are discussed.
\end{abstract}

Keywords: Negev Bedouin; Spelling Accuracy; Gender Differences; Consonants

\section{Introduction}

Bedouin minority comprises $15 \%$ of Arab citizens in Israel according to the Central Bureau of Statistics of Israel (2013). It consists of more than 250,000 Israeli citizens (Ben Sales, 2012), of which approximately $70 \%$ live in the Negev.

Studies conducted in the Bedouin sector in Israel showed very low achievements among the Bedouin students learning in the educational system, and pointed out the existence of illiteracy to some degree, even in high schools (Ben David, 1994). Additional studies reported severe educational difficulties of Bedouin students at school and higher percentage of dropouts from the educational system, compared with other native Arabic non-Bedouin teenagers, and compared with the Hebrew sector (Ben Rabi, Amiel, Nijm, \& Dolev, 2009).

Most of the researches so far focused on mapping the Bedouin dialects (Abdel-Massih \& Bahig, 1978; Abu El-Hij'a, 2012; Al-Wer \& De Jong, 2009; Blanc, 1970; Fischer \& Jastrow, 1980; Holes, 1995a; Holes, 1995b; Shawarba, 2007), with specific attention to the Bedouin dialect of the Galilee in north Israel (Rosenhouse, 1980, 1984, 1995a, 1995b; Rosenhouse \& Katz, 1980), the Bedouin dialects of central and southern Sinai (de Jong, 2011), and outside Israel, for example Bedouin dialects in Jordan (Palva, 2008), Egypt and eastern Lybia (Mitchell, 1960), Iraq (Palva, 2009), and Kuwait (Ayyad, 2011); sociolinguistic aspects and stylistic variation of the Bedouin dialects of the Negev (Henkin, 1992, 1994, 1996, 1998, 2000, 2005, 2007a, 2007b, 2009a, 2009b, 2010, 2011); Bedouin poetry (Bailey, 1991; Holes \& Abu Athera, 2007; Jargy, 1989); anthropological aspects of Bedouin society (Borg, 1999, 2001; Borg \& Kressel, 1995, 2001); Bedouin manners from socio- linguistic point of view (Piamenta, 1979). However, none of these studies has ever explored aspects of language acquisition and specifically the spelling development of the written form of Arabic among Bedouin students in elementary schools from a linguistic point of view, which is the main purpose of this study.

\section{The Phonetic and Phonological System of Arabic}

Arabic is a Semitic language, read and written from right to left. Its alphabetic script consists of print and handwriting systems. Arabic orthography is comprised of 29 letters, which primarily represent consonants, but also include three letters that carry a double function and represent long vowels in some cases. Lexicon words are formed by inserting the root into the word pattern (Berent, Marcus, Shimron, \& Gafos, 2002). All verbs and most nouns are written primarily as three to four letter consonantal roots that are differently affixed and vowelled to form the words of the lexicon (Berman, 1978; Ravid \& Schiff, 2006). The final form of a word in the lexicon is defined by patterns, regularly formed by a combination of vowels and other extra consonants, and produce nouns with number and gender (Shimron, 2003). There are three short vowels which are optionally represented within consonantal graphemes by diacritic vowel marks above or below the body of the word. The short vowels also carry case-marking at the ends of most nouns in the written form of the language.

In addition to the diacritics for the three short vowels, there are additional reading signs that contribute phonology to the Arabic alphabet: the sukūn, which indicates the absence of a vowel, šaddah, which signals doubling of a consonant, hamzah, 
which signals the glottal-stop, maddah, which signals doubling of the letter alif and vowel lengthening, and wașlah, which signals that the alif is not pronounced under certain conditions (Bauer, 1996; Fischer, 1998). All these marks rarely appear in adult texts. Therefore, beginning readers must learn to supply missing vowels to identify what word a string of consonants represents, based on contextual and other available information (Hamada \& Koda, 2008), unless the text is completely vowelled.

Further, 22 of the 29 letters in Arabic are written connected to the following letters, and only six letters are written with no connection to the following letter. In addition to their connectivity, most of the letters that are written connected to the following letter are represented by multiple shapes, and are written differently according to their placement in the word.

Diacritic dots are another integral linguistic characteristic. They are an obligatory part of 15 letters. These letters in Arabic share a similar or even identical basic structure and are distinguished only on the basis of the existence, location and number of dots. Thus, the fact that similar graphemes represent different phonemes, and at the same time different graphemes represent the same phoneme, makes grapheme-phoneme corresponddences quite complex in Arabic.

Several studies in the past few years have pointed out difficulties with the acquisition of the written form of Arabic among native Arabic speakers (Abu Rabia, 2001, 2002; Abu Rabia \& Siegel, 1995; Abu Rabia \& Taha, 2004, 2006; Azzam, 1984, 1993; Bentin \& Ibrahim, 1996; Eviatar, Ibrahim, \& Ganayim, 2004; Ibrahim, Eviatar, \& Aharon-Perez, 2002; Saiegh-Haddad, 2003, 2004, 2005, 2007; Saiegh-Haddad, Levin, Hende, \& Ziv, 2011) For example, it was found that reaction times for visual recognition of Arabic words by senior high school native Arabic skilled readers were longer than reaction times for Hebrew words by native Hebrew high school seniors (Bentin \& Ibrahim, 1996), English words by native English undergraduates, and Serbo-Croatian words by native Serbo-Croatians undergraduates (Frost, Katz, \& Bentin, 1987). It was also found that letter recognition process is faster and more accurate in Hebrew (L2) than in Arabic (L1) among bilingual native Arabic adults (Abu Rabia, 2001). Other studies reported that the reading process in Arabic among native Arabic skilled readers is slower than the reading process in Hebrew among native Hebrew skilled readers (Azzam, 1984, 1993; Ibrahim, Eviatar, \& Aharon-Perez, 2002). It was suggested that the complexity of Arabic orthography imposes a linguistic burden that is created by additional orthographic information in Arabic, as compared with other orthographies, such as the Hebrew orthography (Azzam, 1993; Eviatar, Ibrahim, \& Ganayim, 2004; Ibrahim, Eviatar, \& Aharon-Perez, 2002), and English orthography (Eviatar \& Ibrahim, 2004; Khaldieh, 1996). According to these studies, this linguistic burden of the Arabic orthography plays a significant role in the acquisition of the written form of Arabic, compared with other languages, and may cause a delay in the literary development and in the ability to achieve automatic reading (Ibrahim \& Eviatar, 2001; Ibrahim et al., 2002; Eviatar, Ibrahim, \& Ganayim, 2004; Ibrahim \& Aharon-Peretz, 2005). Trying to better understand the linguistic features that affect the reading process in the written for, of Arabic, a recent study by Taha, Ibrahim and Khateb (2013) among native Arabic skilled readers found that time reaction for connected as opposed to nonconnected word did not present a challenge among the population tested.
An additional important aspect of Arabic is its diglossic nature. Diglossia refers to the existence of two different types of language contact systems of the same language (Trudgill, 2009), high prestigious standard (written) and low prestigious nonstandard (spoken), in the use of the same community. Those two systems significantly differ from one another in vocabulary, and in several aspects of phonology and grammar as well (Ferguson, 1959). In Arabic, the standard literary language coexists with a very divergent colloquial variety. Spoken Arabic is the mother language of all native Arabic speakers, and consists of thousands of dialects, which vary widely along geographical, religious and socioeconomic status from one Arabic speaking community to another (Freha, 1989; Holes, 1995a). However, spoken Arabic is often looked down upon as not "real Arabic" (Henkin, 2010). Literary Arabic is used in written form for formal communication, media, poetry, and prayer, and is learned at school as what some consider a second language (Ayari, 1996; Saiegh-Haddad, 2003). Thus, diglossia, as a salient phenomenon of Arabic, makes Arab speakers bilingual (Eviatar \& Ibrahim, 2000). This complicated linguistic situation was found as the main cause for low reading achievements among Arabspeaking students in Israel in PIRLS 2006 tests (Zuzovsky, 2008). Studies have also shown that diglossia affects linguistic processes, including phonological awareness, reading words and spelling (Abu Rabia \& Taha, 2004; Saiegh-Haddad, 2003, 2004, 2005, 2007).

This study explored spelling development of the written form of Arabic among native Arabic Bedouin second, fourth, and sixth graders from three recognized authorities in south Israel.

\section{Negev Arabic}

Bedouin Arabic dialects differ from sedentary dialects in several linguistic respects (Rosenhouse, 1984). For example, phonologically, the phoneme /q/ in Bedouin dialects is a voiced $[\mathrm{g}]$, while it is pronounced as $[\mathrm{k}],[\mathrm{k}]$, or $[\mathrm{q}]$ in rural areas, and ['] (glottal stop) in urban dialects. In addition, an aXC sequence in Bedouin dialects is broken by a stressable /a/ (X being a back consonant), e.g. gahwah > gaháwah "coffee". Other sedentary vs. Bedouin linguistic differences have been described by Henkin (1996, 2000, 2011), and Rosenhouse (1984: ch. 3). The core of Negev Arabic is a Bedouin heterogeneous dialect with mixed elements in phonology, morphology, prosody, in addition to a register scale (Henkin, 2010).

In this study we focused on developmental aspects of spelling of a sample of seven phonemes, that was selected for the purpose of this study representing all phonemic groups: guttural

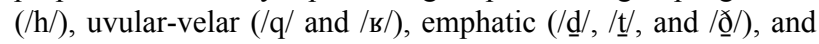
dental $(/ \theta /)$.

\section{Research Aim and Research Question}

What is the developmental trajectory for accurate spelling of consonants (guttural: /h/, uvular-velar: /q/ and /s/, emphatic: /d/, $/ \mathrm{t} /$, and $/ \underline{\mathrm{d}} /$, and dental: $/ \theta /$ ) in the written form of Arabic among native Bedouin speaking students in the second, fourth, and sixth grades?

Based on previous studies among native Arabic students (Abu-Rabia \& Siegel, 1995; Abu-Rabia \& Taha, 2004; SaieghHaddad, 2003, 2004, 2005, 2007), we hypothesized that native Bedouin speakers, like other native Arabic speakers, would make phonological errors, for example errors in representing 
phonemes that do not exist, or phonemes which sound different in their home language, for example the word /qahwah/ (coffee) is pronounced/gahwah/ by native Bedouin speakers. Nonetheless, it had been expected that there will be a significant improvement with spelling accuracy over time: from second to fourth grade, and from fourth to sixth grade as well.

\section{Method}

Participants: The study included 347 elementary school students from second $(\mathrm{N}=105)$, fourth $(\mathrm{N}=113)$, and sixth $(\mathrm{N}=$ 129) grades, boys $(\mathrm{N}=171)$ and girls $(\mathrm{N}=176)$, learning in two recognized Bedouin local authorities in the Negev. The schools are considered to be of average socio-economic background based on an index determined by the Israeli Central Bureau of Statistics (Central Bureau of Statistic, 2013). Students with learning disabilities of any kind were excluded from the sample.

\section{Measures}

Task construction: This study included five experimental tasks that were created for the study: real word dictation, pseudo-word dictation, word recognition, semi-structured writing assignment, and picture story writing assignment. Real word dictation, pseudo-word dictation, and word recognition were based on similar tasks used in Russak \& Fragman (2013).

Real word dictation: This task was comprised of eight real words. Each word included two or three of the phonemegrapheme consonants targeted (See appendix for a list of the real words used in the study). The words were dictated in class by a native Arabic speaker accompanied to the researcher. Each word was dictated three times. A score of 1 or 0 was given based on correct or incorrect spelling for the phonemes targeted only (Cronbach's alpha: .92).

Pseudo-word dictation: Similarly to the previous task, the pseudo-word task was comprised of eight pseudo-words. Each word included two or three of the phoneme-grapheme consonants targeted (See appendix for a list of the pseudo-words used in the study). The pseudo words were created by changing one letter from the real words used in the real word dictation task. For example: //mi $\theta \mathrm{q} a \bar{j} /$ instead of $/ \mathrm{mi} \theta \mathrm{q} a \bar{l} /$ (weigh-scale). The words were read live in class by a native Arabic speaker. Each word was read aloud three times. A score of 1 or 0 was given based on correct or incorrect spelling for the phonemes targeted only (Cronbach's alpha: .91).

Real word recognition: In this task the students were required to recognize correctly spelled words in pairs of words where one word was spelled correctly and the other word was spelled incorrectly as a result of changing one grapheme only, for example حَجْ - حَجّ - This task, which was based on a similar task used by Siegel, Share \& Geva (1995) was comprised of 20 word pairs (Cronbach's alpha: .88). (See appendix for a list of the word pairs used in the study).

Procedure: This study was conducted with the permission of the Ministry of Education Chief Scientist's Office. Data were collected towards the end of the school year by the author in the second, fourth, and sixth grade classrooms. Instructions were given in Arabic, their mother tongue, by a native Bedouin speaker. The order of test administration was altered in order to counterbalance the effects of one task on another. Testing took one full 45 minute lesson.

\section{Results}

This study explored spelling development of the written form of Arabic among Bedouin Arabic speaking second, fourth, and sixth graders with specific attention to the acquisition of gut-

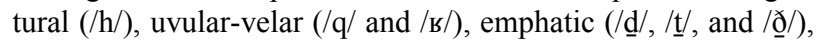
and dental $(/ \theta /)$ consonants. Table 1 shows descriptive statistics of performance across grades for real-word dictation, pseudoword dictation, and word recognition tasks.

In order to explore the effect of grade level on spelling, a series of repeated measure ANOVA analyses with grade as the between subject factor and task as the within subject factor were performed. Main effects were found for grade $\mathrm{F}(2,341)=$ $20.30, p<.01$, for task $\mathrm{F}(2,341)=127.19, p<.01$, and also for gender $F(1,341)=11.07, p<.01$. Bonferroni post hoc analyses showed that scores in fourth grade $(87.99 \%)$ and in the sixth grade $(86.09 \%)$ were significantly higher than scores in the second grade $(74.59 \%)$ for all tasks, however there was no significant difference between the fourth and the sixth grade. In addition, there was significant difference in scores for all tasks: scores for word recognition task were the highest $(89.80 \%)$, following scores for real-word dictation $(81.34 \%)$, and pseudoword dictation $(77.53 \%)$. Bonferroni post hoc analyses also showed that scores were significantly higher among female students $(85.89 \%)$ than among male students $(79.89 \%)$ for all tasks. According to the above analyses, two additional years of exposure and practice of the written form of Arabic, between the fourth and the sixth grades among native Arab Bedouin speakers, do not affect their spelling performance.

The question of this study was concerned with the developmental trajectory for accurate spelling of consonants (guttural: /h/, uvular-velar: /q/ and /s/, emphatic: / $\underline{\mathrm{d}} /, / \underline{\mathrm{t}} /$, and $/ \underline{\mathrm{d}} /$, and dental: $/ \theta /)$ in the written form of Arabic among native Bedouin second, fourth, and sixth graders for all tasks used in this study. Table 2 shows descriptive statistics of mean percentage scores for each of the consonants targeted across grades for real word dictation task.

In order to examine the developmental trajectory for the targeted consonants across grades, a 3-way ANOVA analysis with consonants and task as within subject factors and grade as between subject factors was done. Main effect for consonants

Table 1.

Descriptive statistics of real-word, pseudo-word, and word recognition tasks: mean percentage scores by grade and task.

\begin{tabular}{cccc}
\hline & $2^{\text {nd }}$ grade M(SD) & $4^{\text {th }}$ grade M(SD) & $6^{\text {th }}$ grade M(SD) \\
\hline Real word dictation & $71.93(1.97)$ & $87.12(1.87)$ & $84.98(1.77)$ \\
Pseudo word dictation & $70.58(1.97)$ & $82.61(1.87)$ & $79.39(1.76)$ \\
Word recognition & $81.26(1.55)$ & $94.26(1.47)$ & $89.56(13.10)$ \\
\hline
\end{tabular}


Table 2.

Descriptive statistics of mean percentage scores for consonants targeted across grades - real word task.

\begin{tabular}{cccc}
\hline & $2^{\text {nd }}$ grade $\mathrm{M}(\mathrm{SD})$ & $4^{\text {th }}$ grade $\mathrm{M}(\mathrm{SD})$ & $6^{\text {th }}$ grade M(SD) \\
\hline Guttural & $87.85(1.84)$ & $98.79(1.75)$ & $94.86(1.65)$ \\
Uvular-velar & $80.05(2.15)$ & $94.22(2.04)$ & $89.73(1.93)$ \\
Emphatic & $50.78(2.69)$ & $69.02(2.55)$ & $72.29(2.41)$ \\
Dental & $72.90(3.11)$ & $88.51(2.95)$ & $82.09(2.79)$ \\
\hline
\end{tabular}

showed significant differences between all consonantal groups $\mathrm{F}(3,341)=178.25, p<.00$. Bonferroni post hoc analyses showed that the scores for guttural consonants were the highest $(93.84 \%)$, followed by uvular-velar consonants $(87.99 \%)$, dental consonants $(81.17 \%)$, and emphatic consonants respectively $(64.03 \%)$ with significant differences between scores for each of the consonantal group. Table 3 shows descriptive statistics of mean percentage scores for each of the consonants targeted across grades for pseudo-word dictation task.

Main effect for consonants showed significant differences between all consonantal groups $\mathrm{F}(3,341)=259.92, p=.00$. Bonferroni post hoc analyses showed that the scores for guttural consonants were the highest $(90.75 \%)$, followed by uvular-velar consonants (84.66\%), dental consonants $(73.39 \%)$, and emphatic consonants respectively $(53.14 \%)$ with significant differences between scores for each of the consonantal group, similarly to the results achieved for the real word task.

In the task of word recognition, we focused on guttural $(/ \mathrm{h} /)$, uvular-velar (/q/, / / / ) , and emphatic (/d/, / t $/)$ consonants only, which have a pair-phoneme which sounds similar to each of them (Russak \& Fragman, 2013). According to Russak \& Fragman (2013), the dental consonant $/ \theta /$ does not have a pairphoneme. Therefore, it had been decided not to include this phoneme in the word recognition task. Table 4 shows descriptive statistics of mean percentage scores for each of the consonants targeted across grades for word recognition task.

A main effect was found for sound $\mathrm{F}(2,341)=14.051, p$ $=.00$. Bonferroni post hoc analyses showed that while scores for all consonantal groups were significantly different from each other in the second grade, with the highest scores for the guttural phonemes, followed by uvular-velar phonemes, and em phatic phonemes respectively, scores for all the consonantal groups significantly improved in the fourth grade. Scores for the emphatic phonemes significantly improved in the sixth grade as well, reaching a similar level of accuracy to the other phonemes targeted.

\section{Discussion}

This study explored spelling development of the written form of Arabic among native Bedouin Arabic speaking second, fourth, and sixth graders with specific attention to the acquisi-

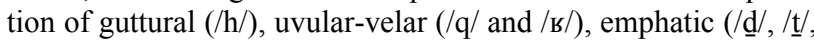
and $/ \underline{\varrho} /)$, and dental $(/ \theta /)$ phonemes.

The results indicate significant improvement in the representation of the consonants targeted from second grade to the fourth grade. However, there was no significant improvement from the fourth grade to the sixth grade. This phenomenon of spelling errors in the written form of the language had already been discussed by Abu Rabia \& Taha (2004, 2006), who found that $50 \%$ of all errors were phonological among native $1^{\text {st }}$ to $9^{\text {th }}$
Table 3.

Descriptive statistics of mean percentage scores for consonants targeted across grades-pseudo-word task.

\begin{tabular}{cccc}
\hline & $2^{\text {nd }} \operatorname{grade}$ M(SD) & $4^{\text {th }}$ grade M(SD) & $6^{\text {th }}$ grade M(SD) \\
\hline Guttural & $83.92(2.11)$ & $96.74(2.00)$ & $91.61(1.89)$ \\
Uvular-velar & $76.32(2.11)$ & $90.81(2.00)$ & $86.85(1.89)$ \\
Emphatic & $48.95(2.92)$ & $53.56(2.77)$ & $56.91(2.62)$ \\
Dental & $66.37(2.94)$ & $80.23(2.79)$ & $73.59(2.63)$ \\
\hline
\end{tabular}

Table 4.

Descriptive statistics of mean percentage scores for consonants targeted across grades - word recognition task.

\begin{tabular}{cccc}
\hline & $2^{\text {nd }}$ grade M(SD) & $4^{\text {th }}$ grade M(SD) & $6^{\text {th }}$ grade M(SD) \\
\hline Guttural & $84.21(1.66)$ & $95.40(1.57)$ & $93.61(1.48)$ \\
Uvular-velar & $77.62(2.03)$ & $89.71(1.93)$ & $93.14(1.82)$ \\
Emphatic & $80.81(1.73)$ & $95.89(1.64)$ & $94.56(1.55)$ \\
\hline
\end{tabular}

Arabic graders. They further claimed that the phonological stage of spelling in Arabic does not seem to end even in the end of junior high school, unlike Latin orthographies where children are already expected to pass from the phonological stage to transitional and correct stages at younger age (Gentry, 1982). The results of this study support their findings that diglossic phonology continues to affect native Arabic speakers, as well as Bedouin spellers of Arabic, not only in the kindergarten (Saiegh-Haddad, 2003) but also at higher levels in the primary school (Abu-Rabia \& Taha, 2004, 2006). It is interesting though, that various results were found in different studies regarding the acquisition of consonants. While Amayreh (2003) found that all consonants were expected to be acquired by native Jordanian speakers approximately at the age of 8:6 - 9:0 (fourth grade), the results of this study show that spelling errors of similar phonemes in Arabic or spelling errors as a result of diglossia (Saiegh-Haddad, 2003, 2004, 2005, 2007; Hamdan \& Amayreh, 2007) occur even in the end of elementary school, while full proficiency in the standard form of Arabic may be achieved only at later age (Al-Rabaa, 1986).

It is also interesting to note that native Bedouin speakers who participated in this study found specific difficulty representing emphatic phonemes in the written form of Arabic, and represented them by a similar phoneme. This phenomenon can be explained by the complexity of Arabic phonology (Abu Rabia \& Taha, 2004, 2006) and specifically the phonological similarity within the Arabic phonological inventory, for example 
between $/ \omega /$ and $/ \omega /$, but also between the emphatic phonemes / $/$ / $/$ / and, which both are pronounced / $/$ / in the Negev Arabic. Similar findings were found by Abu Rabia \& Siegel (1995) among native Arabic $8^{\text {th }}$ graders. Similar results regarding the representation of emphatic phonemes in the written form of Arabic in various studies among native Arabic speakers show that the acquisition of emphatic phonemes in Arabic seems to be more complicated than the acquisition of other phonemes, for example guttural and uvular-velar phonemes, as a result of the unique secondary articulation feature of pharyngealization for the emphatic phonemes (Amayreh \& Dyson, 1998). As pharyngealization is not as salient a phonetic feature as place of articulation, distinguishing between phonemes based on differences with this particular secondary phonetic feature alone is challenging, and therefore extends over a longer period than the acquisition of other phonemes among native Arabic speakers learning the written form of Arabic as a second language (Ayari, 1996; Saiegh-Haddad, 2003).

Another important result of this study relates to gender differences. The results of this study indicate that female students scored significantly better than male students in all tasks and in all grades. While most of the literatures on gender differences focus on reading, there is not much on the development of spelling proficiency, and most of the assumptions about spelling are drawn from reading research (Mohamed, Elbert, \& Landerl, 2011). Several studies indicated that female students are expected to outperform male students in verbal and oral skills, and in reading tests as well (Allred, 1990; Horne, 2007). However, other studies have not found consistent differences between females and males (Horne, 2007; Hyde \& Linn, 1988; Millar \& Barber, 1981; Mohamed et al., 2011). Hyde and Linn (1988) have suggested that the overall magnitude of gender differences in the samples targeted for these studies was quite small. Going back to the gender differences of our study, we find average of six points difference between female and male students in elementary school in favor of females. At this point of the study, we cannot make further suggestions whether gender differences in this study stem from socialization and cultural influences (Feingold, 1988; Richardson, 1997), or from cognitive biologically determined abilities (Kimura, 1999). However, although this difference is consistent from second to sixth grade, bridging this gap does not seem unachievable. Further, it seems that female literary advantage lies within the normal scale (Lynn, 1994, 1999). Yet, further research is needed among native Bedouin speakers of junior high school and high school graders in order to explore whether male students compare with female students in high school grades.

Taken as a whole, reasons for lack of improvement in spelling accuracy from fourth to sixth grade on the one hand should be carefully considered. A possible explanation for stagnation in spelling development can be attributed to the difficulty of elementary graders with the acquisition of emphatic phonemes which affects their general spelling proficiency. In addition, some of these emphatic phonemes occur infrequently in the written form of Arabic, for example /ض/ and / $/$ / (Madi, 2010). In order to enhance spelling proficiency, language teachers should initiate literary activities as much as possible, with specific attention to spelling and to the ongoing difficulty with the accurate representation of emphatic phonemes in the written form of Arabic. Educators should also be aware to the fact that female students achieve higher scores in spelling tasks than their male counterparts along elementary grades. However, this gap does not seem unbridgeable. Therefore, we recommend that educators and language teachers make sure that this gap is reduced over time towards the end of junior high school and high school grades.

\section{Acknowledgements}

This study was generously supported by a grant from The Robert H. Arnow Center for Bedouin Studies and Development, Ben-Gurion University of the Negev, and Beit Berl Academic College.

I also wish to thank Prof. Roni Henkin for her enlightening remarks.

\section{REFERENCES}

Abdel-Massih, E. T., \& Bahig, A. F. (1978). A comprehensive study of Egyptian Arabic. Ann Arbor, MI: Center for Near Eastern and North African Studies, University of Michigan.

Abu El-Hij'a, D. (2012). Facebook written Levantine vernacular languages. The Levantine Review, 1, 68-105.

Abu-Rabia, S. (2001). The role of vowels in reading Semitic scripts: Data from Arabic and Hebrew. Reading and Writing: An Interdisciplinary Journal, 14, 39-59.

http://dx.doi.org/10.1023/A:1008147606320

Abu-Rabia, S. (2002). Reading in a root-based morphology language. Journal of Research in Reading, 25, 299-309. http://dx.doi.org/10.1111/1467-9817.00177

Abu-Rabia, S., \& Siegel, L. S. (1995). Different orthographies, different context effects: The effects of Arabic sentence context on skilled and poor readers. Reading Psychology, 16, 1-19. http://dx.doi.org/10.1080/0270271950160101

Abu Rabia, S., \& Taha, H. (2004). Reading and spelling error of native Arabic dyslexic readers. Reading and Writing: An Interdisciplinary Journal, 17, 651-689. http://dx.doi.org/10.1007/s11145-004-2657-x

Abu Rabia, S., \& Taha, H. (2006). Phonological errors predominate in Arabic spelling across grades 1 - 9. Journal of Psycholinguistic Research, 35, 167-188. http://dx.doi.org/10.1007/s10936-005-9010-7

Al-Rabaa, S. (1986). Diglossia in the classroom: The Arabic case. Anthropological Linguistics, 28, 73-79.

Allred, P. G. (1990). Gender differences in spelling achievement in grades 1 through 6. Journal of Educational Research, 83, 187-193.

Al-Wer, E., \& De Jong, R. (2009). Arabic dialectology. Leiden: Brill. http://dx.doi.org/10.1163/ej.9789004172128.i-298

Amayreh, M. M., \& Dyson, A. T. (1998). The acquisition of Arabic consonants. Journal of Speech, Language, and Hearing Research, 41, 642-653.

Amayreh, M. (2003). Completion of the consonant inventory of Arabic. Journal of Speech, Language, and Hearing Research, 46, 517-529. http://dx.doi.org/10.1044/1092-4388(2003/042)

Ayari, S. (1996). Diglossia and illiteracy in the Arab world. Language Culture and Curriculum, 9, 243-253. http://dx.doi.org/10.1080/07908319609525233

Ayyad, H. S. (2011). Phonological development of typically developing Kuwaiti Arabic-speaking preschoolers. Ph.D. Thesis, Columbia: The University of British Columbia.

Azzam, R. (1984). Orthography and reading of the Arabic language. In J. Aaron, \& R. M. Joshi (Eds.), Reading and writing disorders in different orthographic systems (pp. 1-29). Dordrecht: Kluwer Academic Publishers.

Azzam, R, (1993). The nature of Arabic reading and spelling errors of young children. Reading and Writing: An Interdisciplinary Journal, 5, 355-385. http://dx.doi.org/10.1007/BF01043112

Bailey, C. (1991). Bedouin poetry from Sinai and the Negev: Mirror of a culture. Oxford: Clarendon Press.

Bauer, T. (1996). Arabic writing. In P. Daniels, \& P. Bright (Eds.), The world's writing systems (pp. 559-564). New York: Oxford University Press. 
Ben-David, J. (1994). The Bedouin education system in the Negev: reality and need to promote it. Jerusalem: Floersheimer Institute for Policy Studies. (in Hebrew)

Ben Rabi, D., Amiel, S., Nijim, F., \& Dolev, T. (2009). Bedouin children in the Negev: Characteristics, needs and patterns of service use. Jerusalem: Myers-JDC-Brookdale Institute.

Bentin, S., \& Ibrahim, R. (1996). New evidence for phonological processing during visual word recognition: The case of Arabic. Journal of Experimental Psychology, 22, 309-323.

Berent, I., Marcus, G. F., Shimron, J., \& Gafos, A. I. (2002). The scope of linguistic generalizations: Evidence from Hebrew word formation. Cognition, 83, 113-139.

http://dx.doi.org/10.1016/S0010-0277(01)00167-6

Berman, R.A. (1978). Modern Hebrew structure. Tel Aviv: University Publishing.

Blanc, H. (1970). The Arabic Dialect of the Negev Bedouins. Jerusalem: Israel Academy of sciences and Humanities.

Central Bureau of Statistics (2013). Israel.

http://www1.cbs.gov.il/reader/newhodaot/hodaa template.html?hoda $\mathrm{a}=201211106$

De Jong, R. E. (2011). A grammar of the Bedouin dialects of central and southern Sinai. Leiden: Brill. http://dx.doi.org/10.1163/ej.9789004201019.i-440

Eviatar, Z., \& Ibrahim, R. (2000). Bilingual is as bilingual does: Metalinguistic abilities of Arab-speaking children. Applied Psycholinguistics, 21, 451-471. http://dx.doi.org/10.1017/S0142716400004021

Eviatar, Z., \& Ibrahim, R. (2004). Morphological and orthographic effects on hemispheric processing of nonwords: A cross-linguistic comparison. Reading and Writing: An Interdisciplinary Journal, 17, 691-705. http://dx.doi.org/10.1007/s11145-004-2659-8

Eviatar, Z., Ibrahim, R., \& Ganayim, D. (2004). Orthography and the hemispheres: Visual and linguistic aspects. Neuropsychology, 18, 174-184. http://dx.doi.org/10.1037/0894-4105.18.1.174

Feingold, A. (1988). Cognitive gender differences are disappearing. American Psychologist, 43, 95-103.

http://dx.doi.org/10.1037/0003-066X.43.2.95

Ferguson, C. A. (1959). Diglossia. Word, 15, 325-340.

Fischer, W., \& Jastrow, J. (1980). Handbook of oriental studies. Leiden: Brill.

Fischer, W. (1998). Classical Arabic. In R. Hetzron (Ed.). The Semitic languages (pp. 187-219). New York: Routledge.

Freha, A. (1989). The dialects and the methods of studying them. Beirut: Dar Aljeel.

Frost, R., Katz, L., \& Bentin, S. (1987). Strategies for visual word recognition and orthographical depth: A multilingual comparison. Journal of Experimental Psychology: Human Perception and Performance, 13, 104-115. http://dx.doi.org/10.1037/0096-1523.13.1.104

Gentry, J. R. (1982). An analysis of developmental spelling in GNYS AT WRK. The Reading Teacher, 36, 192-200.

Hamada, M., \& Koda, K. (2008). Influence of first language orthographic experience on second language decoding and word learning. Language Learning, 58, 1-31. http://dx.doi.org/10.1111/j.1467-9922.2007.00433.x

Hamdan, J. M., \& Amayreh, M. M. (2007). Consonant profile of Arabic-speaking school-age children in Jordan. Folia Phoniatr Logop, 59, 55-64. http://dx.doi.org/10.1159/000098338

Henkin, R. (1992). The three faces of the Arabic participle in Negev Bedouin dialects: Continuous, resultative, and evidential. Bulletin of the school of Oriental and African Studies, 55, 433-444. http://dx.doi.org/10.1017/S0041977X00003633

Henkin, R. (1994). On the narrative imperative in Negev Arabic and Russian. Journal of Semitic studies, 39, 245-283. http://dx.doi.org/10.1093/jss/XXXIX.2.245

Henkin, R. (1996). Negev Bedouin vs. sedentary Palestinian narrative style. In S. Isra'el, \& S. Raz (Eds.), Israel oriental studies XVI: Studies in modern Semitic languages (pp.169-192). Leiden: BRILL.

Henkin, R. (1998). Narrative styles of Palestinian Bedouin adults and children. Pragmatics, 8, 47-78.

Henkin, R. (2000). Narrative styles of Negev Bedouin men and women.
Oriente Moderno, 19, 59-81.

Henkin, R. (2005). Task-related variation in tense usage in ArabicHebrew interlanguage, In D. Diskin-Ravid, \& H. Bat-Zeev Shyldkrot (Eds.), Perspectives on language and language development (pp. 393-405). New York: Kluwer Academic Publishers. http://dx.doi.org/10.1007/1-4020-7911-7_28

Henkin, R. (2007a). Negev Arabic. encyclopedia of Arabic language and linguistics 3 (pp. 360-369). Leiden: Brill Academic Publishers.

Henkin, R. (2007b). Swaying on the scale from standard to sound when writing non-written dialects. In T. Bar, \& E. Cohen (Eds.), Studies in semitic and general linguistics in honor of Gideon Goldenberg (pp. 45-73). Münster: Alter Orient und Altes Testament Band 334.

Henkin, R. (2009a). How interdialectal is peripheral oral Bedouin poetry? In G. Goldenberg, \& A. Shisha-Halevy (Eds.), Egyptian, semitic and general grammar: Workshop in memory of H. J. Polotsky (pp. 239-269). Jerusalem: The Israel Academy of Sciences and Humanities.

Henkin, R. (2009b). The cognate curse in Negev Arabic: From playful punning to coexistence conflicts. Israel Studies in Language and Society, 2, 169-206.

Henkin, R. (2010). Negev Arabic: Dialectal, sociolinguistic, and stylistic variation. Semitica Viva Series. Wiesbaden: Otto Harrassowitz.

Henkin, R. (2011). Hebrew and Arabic asymmetric contact in Israel. Lodz Papers in Pragmatics, 7, 61-100.

Ho, C. S. H., \& Bryant, P. (1999). Different visual skills are important in learning to read English and Chinese. Educational and Child Psychology, 16, 4-14.

Holes, C. (1995a). Modern Arabic: Structures, functions, and varieties. London: Longman.

Holes, C. (1995b). Community, dialect and urbanization in the Arabicspeaking Middle East. Bulletin of the School of Oriental and African Studies, 58, 270-287.

http://dx.doi.org/10.1017/S0041977X00010764

Horne, J. K. (2007) Gender differences in computerised and conventional educational tests. Journal of Computer Assisted Learning, 23, 47-55. http://dx.doi.org/10.1111/j.1365-2729.2007.00198.x

Hyde, J. S., \& Linn, M. C. (1988). Gender differences in verbal ability: A meta-analysis. Psychological Bulletin, 104, 53-69. http://dx.doi.org/10.1037/0033-2909.104.1.53

Ibrahim, R., \& Aharon-Peretz, J. (2005). Is literary Arabic a second language for native Arab speakers? Evidence from a semantic priming study. The Journal of Psycholinguistic Research, 34, 51-70. http://dx.doi.org/10.1007/s10936-005-3631-8

Ibrahim, R., Eviatar, Z., \& Aharon Peretz, J. (2002). The characteristics of the Arabic orthography slow its cognitive processing. Neuropsychology, 16, 322-326. http://dx.doi.org/10.1037/0894-4105.16.3.322

Jargy, S. (1989). Sung Poetry in the oral tradition of the Gulf region and the Arabian Peninsula. Oral Tradition, 4, 174-188.

Khaldieh, S. (1996). Word recognition of Arabic as a foreign language by American learners: The role of phonology and script. Al-'Arabiyya, 29, 129-152.

Kimura, D. (1999). Sex and cognition. Cambridge, MA: MIT Press.

Lynn, R. (1994). Sex differences in brain size and intelligence: A paradox resolved. Personality and Individual Differences, 17, 257-271. http://dx.doi.org/10.1016/0191-8869(94)90030-2

Lynn, R. (1999). Sex differences in intelligence and brain size: A developmental hypothesis. Intelligence, 27, 1-12. http://dx.doi.org/10.1016/S0160-2896(99)00009-4

Madi, M. (2010). A study of Arabic letter frequency analysis. URL (last checked 23 July 2013).

http://www.intellaren.com/articles/en/a-study-of-arabic-letter-freque ncy-analysis

Mitchell, T. F. (1960). Prominance and syllabication in Arabic. Bulletin of the School of Oriental and African Studies, 23, 369-389. http://dx.doi.org/10.1017/S0041977X00149997

Mohamed, W., Elbert, T., \& Landerl, K. (2011). The development of reading and spelling abilities in the first 3 years of learning Arabic. Reading and Writing: An Interdisciplinary Journal, 24, 1043-1060. http://dx.doi.org/10.1007/s11145-010-9249-8 
Palva, H. (2008). Sedentary and Bedouin dialects in contact: Remarks on Karaki and Salti (Jordan). Journal of Arabic and Islamic Studies, 8, 53-70.

Palva, H. (2009). From qəltu to gələt: Diachronic notes on linguistic adaptation in Muslim Baghdad Arabic. In E. Al-Wer, \& R. E. de Jong, (Eds.), Arab dialectology: In honor of Clive Holes on the occasion of his sixtieth birthday (pp. 17-40). Leiden: Brill. http://dx.doi.org/10.1163/ej.9789004172128.i-298.12

Ravid, D., \& Schiff, R. (2006). Roots and patterns in Hebrew language development: Evidence from written morphological analogies. Reading and Writing: An Interdisciplinary Journal, 19, 789-818. http://dx.doi.org/10.1007/s11145-006-9004-3

Richardson, J. T. E. (1997). Introduction to the study of gender differences in cognition. In P. Caplan, M. Crawford, J. S. Hyde, \& J. T. E. Richardson (Eds.), Gender differences in human cognition (pp. 81-130). New York: Oxford University Press.

Rosenhouse, J. (1980). The dialects of Shibli and Aramsha in the Galilee. In J. Rosenhouse (Ed.), Texts in the dialects of Bedouins in Israel. Occasional papers on the Middle East 3 (pp. 6-49). Haifa: The University of Haifa.

Rosenhouse, J. (1984). The Bedouin Dialects. Wiesbaden: Otto Harrassowitz.

Rosenhouse, J. (1995a). An Arabic Bedouin story and its linguistic analysis. Zeitschrift für arabische Linguistik, 30, 62-83.

Rosenhouse, J. (1995b). Features of intonation in Bedouin Arabic narratives of the Galilee (North Israel). In T. Harviainen, \& A. Parpola (Eds.), Dialectologia Arabica: A collection of articles in honor of the sixtieth birthday of professor H. Palva, studia orientalia (pp. 193215). Helsinky: Finnish Oriental society.

Rosenhouse, J., \& Katz, J. (1980). Texts in Bedouin dialects in Israel. Haifa: Haifa University.

Russak, S., \& Fragman, A. (2013). The development of grapho-phonemic representation among native Hebrew speakers learning Arabic as a foreign language. In E. Saiegh-Haddad, \& M. Joshi (Eds.), Handbook of Arabic Literacy. London \& New York: Springer. (in Print)

Saiegh-Haddad, E. (2003). Linguistic distance and initial reading acquisition: The case of Arabic diglossia. Applied Psycholinguistics, 24, 431-451. http://dx.doi.org/10.1017/S0142716403000225
Saiegh-Haddad, E. (2004). The impact of phonemic and lexical distance on the phonological analysis of words and pseudowords in a diglossic context. Applied Psycholinguistics, 25, 495-512. http://dx.doi.org/10.1017/S0142716404001249

Saiegh-Haddad, E. (2005). Correlates of reading fluency in Arabic: Diglossic and orthographic factors, Reading and Writing: An Interdisciplinary Journal, 18, 559-582. http://dx.doi.org/10.1007/s11145-005-3180-4

Saiegh-Haddad, E. (2007). Linguistic constraints on children's ability phonemes in Arabic. Applied Psycholinguistics, 28, 607-626. http://dx.doi.org/10.1017/S0142716407070336

Saiegh-Haddad, E., Levin, I., Hende, N., \& Ziv, M. (2011). The linguistic affiliation constraint and phoneme recognition in diglossic Arabic. Journal of Child Language, 38, 297-315. http://dx.doi.org/10.1017/S0305000909990365

Shawarbah, M. (2007). The Bedouin dialect of the Tiyaha in the Negev: Phonology, morphology, and some selected syntactic issues. Ph.D. Thesis, Jerusalem: Hebrew University.

Shimron, J. (2003). Semitic languages: Are they really root-based? In J. Shimron (Ed.), Language processing and acquisition in languages of semitic, root-based, morphology (pp. 1-28). Amsterdam: John Benjamins.

Siegel, L. S., Share, D., \& Geva, E. (1995). Evidence for superior orthographic skills in dyslexics. Psychological Science, 6, 250-254. http://dx.doi.org/10.1111/j.1467-9280.1995.tb00601.x

Taha, H., Ibrahim, R., \& Khateb, A. (2013). How does Arabic orthographic connectivity modulate brain activity during visual word recognition: An ERP study. Brain Topography, 26, 292-302. http://dx.doi.org/10.1007/s10548-012-0241-2

Trudgill, P. (2009). Contact, isolation, and complexity in Arabic. In E. Al-Wer, \& R. De Jong (Eds.), Arabic dialectology (pp. 173-186). Leiden: Brill. http://dx.doi.org/10.1163/ej.9789004172128.i-298.65

Zuzovsky, R. (2008). Capturing the dynamics behind the narrowing achievement gap between Hebrew-speaking and Arab-speaking schools in Israel: Findings from TIMSS 1999 and 2003. Educational Research and Evaluation, 14, 47-71.

http://dx.doi.org/10.1080/13803610801896562 